\title{
Worldview Diagnostic Tree - Educational Instrument for Enhanced Pedagogy on Spirituality and Religion
}

\author{
Shaynah Neshama-Bannister ${ }^{1}$ \\ ${ }^{1}$ Department of Social Work, Azusa Pacific University, Azusa, USA \\ Correspondence: Shaynah Neshama-Bannister, Assistant Professor, Department of Social Work, Azusa Pacific \\ University, Azusa, CA 91702-7000, USA.
}

Received: January 29, 2016

Accepted: February 15, 2016

Online Published: March 2, 2016

doi:10.5430/irhe.v1n1p192

URL: http://dx.doi.org/10.5430/irhe.v1n1p192

\begin{abstract}
Recent, 21st century developments in the mental health field encourage the practical integration of many diverse forms of spiritual and religious practices. Belief systems such as moral relativism, naturalism, New Age philosophy and postmodernism are deeply imbedded in the culture and find direct implementation into the therapeutic treatment process. Graduating students, however, are not adequately prepared to face the spiritual and religious diversity of the professional field. The Worldview Diagnostic Tree is a pedagogical instrument designed to address the identified problem. It has a two-fold function: equipping students with a tool for assessing their own spiritual orientation and assessing their clients' spiritual orientation as well. This educational tool for classroom pedagogy on the integration of spirituality and religion in social work curricula meets EPAS requirements for competent social work practice.
\end{abstract}

Keywords: spirituality, religion, pedagogy, assessment, worldview

\section{Introduction}

Training on spirituality and religion as an intrinsic part of the masters of social work (MSW) curricula is gaining wide recognition in academia. The practice is a required competency set by the new 2015 Educational Policy and Accreditation Standards (EPAS) of the Council of Social Work Education (CSWE). Recent, 21st century developments in the field, however, have made the task difficult. Belief systems such as moral relativism, naturalism, pantheism, New Age philosophy and postmodernism are deeply imbedded in the culture and are massively infused into the therapeutic treatment process. Graduating students find themselves inadequately prepared to face the spiritual and religious diversity that spills into the professional field (Canda \& Furman, 2010).

The academic institutions have recognized the urgency of the task and are currently introducing innovative pedagogies on spirituality and religion into their curricula (Adams, Puig, Baggs \& Wolf, 2015; Hunt, 2014; Zucker, 2014; Clarke, 2012; Mulder, 2014; Todd, 2012; Vokey, 2012; Stirling et al. 2010; Moss, 2005). The development of the Worldview Diagnostic Tree is part of this effort. It serves as an educational instrument for enhanced pedagogy on training spiritually competent social workers. It has a two-fold function: 1) assisting students in identifying their own worldviews, and 2) training students to use the Worldview Diagnostic Tree as a spiritual assessment tool with clients. Based on literature review and field observations, we hypothesize that there will be discrepancies between MSW students' self-identified religious affiliations and their religious identification as measured through the Worldview Diagnostic Tree (WDT) instrument.

\section{Historical Background on Societal Interest in Spirituality and Religion}

American religious behavior has changed very little over the last century. According to a Gallup research poll in 2014, 86 percent of U.S. adults said they believed in God. This finding has remained comparatively high for the last 70 years, when in 1944 the Gallup Poll first asked this question (Bishop, 1999). Chaves' (2011) analysis on the outcome of two major longitudinal surveys, General Social Survey and Gallup Polls, captured almost identical trends: the gradual decline in the concept of an inerrant Bible as well as in church attendance throughout the $20^{\text {th }}$ century have leveled out at the beginning of the $21^{\text {st }}$ century. Despite the identified decline, almost everyone, 93 percent, still believes in God or a higher power. Moreover, Chaves (2011) further concludes that "although people born in the 1940s are much less likely to believe in an inerrant Bible than people born in the 1910s, those born in the 1970s and 1980s are not less likely to believe in an inerrant Bible than those in the 1940s." (Chaves, 2011, p. 33-35)

The above picture of Americans' unwavering level of religious beliefs is further compounded by another parallel development: America's religious landscape is currently defined by growing diffused spirituality (King \& Trimble, 2013; Richards \& Bergin, 1997). The high percentage of those who believe in a God is coupled with proportionally 
high levels of diversity of professed beliefs. The picture is further augmented by those 22 percent who, in 2008 , claimed no religious affiliation (17 percent of the U.S. population) but identified themselves as "spiritual but not religious". These individuals comprise the fourth largest religious tradition in the United States (Lugo et al., 2008) and are considered to be the fastest growing segment in America that define the overt expression of spiritual trends in the public arena (Chaves, 2011). Bender (2010) captured this trend and identified it as the new metaphysics of alternative spirituality in pursuit of the sacred.

The current resurgence of public interest in the practical application of spirituality and the search for the sacred were coupled with resurgence in public interest in the search of the sacred in therapeutic mental health services (Gerson, Allen, Gold, \& Kose, 2000). Various surveys of diverse client populations indicate strong desires for incorporation of spiritual interventions into the mental health practice (Hodge, 2005; Rose et al., 2001). A Gallup study found that 81 percent of the general public desired to have their own spiritual values and beliefs integrated into the therapeutic process (Bart, 1998). These findings are indicative of the clients' formative power in shaping contemporary therapeutic strategies. The above-identified gap between training efficacy and practice demand have prompted numerous attempts for curriculum redesign that takes into consideration the need for infusion of spirituality and religion in the academic program (Alice, 2015; Buckey, 2012; Barker, 2007).

\section{Rationale for Worldview Scale as Pedagogical Instrument}

Good learning presupposes an environment diverse with opinions and views on the subject matter. Because classroom spiritual and religious diversity naturally mirrors the societal diversity, it creates the desired conditions for such internalized learning. The many worldviews exhibited within one student cohort constitute the basis on which the pedagogy on spirituality and religion in social work training may be built. Along with the major religious traditions, many other forms of spirituality are equally represented. Beliefs systems like moral relativism, naturalism, the New Age, postmodernism, and salvation by therapy, are worldviews frequently represented in classroom settings. These, however, are not intellectual systems that are rationally conceived but rather an experiential knowledge - a matter of the heart, not the reason (Wilkens \& Sanford, 2009; Zacharias, 2004; Groothuis, 2004).

Along with desirable benefits, spiritual and religious diversity may also have an adverse effect: blurred boundaries between diverse forms of beliefs and practices may impede students' ability to self-identify with the tenets of their professed religion or identify the tenets of their clients' religious background. Studies have found that even self-professed Christian students are not familiar with the precepts or the doctrines of their acknowledged tradition. These observations are consistent with Barna's (2009) findings that only 9\% of all American adults have a biblical worldview and even among "born again" Christians only $19 \%$ have a biblical worldview, concluding that even the Christian population is quickly becoming influenced by postmodernistic thinking and lacks a biblical worldview.

Studies with college students also identified a significant disconnect between individuals' subjective conceptualizations of religion and spirituality and those found in the Bible. Further findings attest that students' understanding of those concepts only loosely reflects the general understanding within the higher education literature (Craft, 2011).

Present-day postmodernistic philosophy is the dominant overarching frame of reference that has penetrated all spheres of contemporary life, realms of thought and areas of practice (Danto, 2008). Current MSW students are representatives of this particular generation. Personal observations support the fact that very often MSW students are not able to articulate the beliefs and value system that represent their worldviews. Often self-professed Christian students exhibit beliefs incompatible with the Christian faith. For example, the assertion that moral values should change as society changes doesn't align with the values and the doctrines of the Christian faith. Biblical ethics sets firm and unchangeable moral and ethical standards for biblically congruent conduct.

There is thus urgency in addressing the task for adequately teaching an audience that appears to lack the language, the concept or the doctrines for basic understanding of the major faith traditions. Acquiring practical skills for spiritually oriented interventions is a desirable end of a successful pedagogy. The ability, however, to identify the doctrinal and philosophical origin of these interventions is a prerequisite of successful curriculum development. A module on worldview-as-life-disposition integrated into the curriculum would suffice this task. It is an additional pedagogical tool for assisting students to develop professional social work ethical and professional behaviors (Competency \#1 of the CSWE 2015 Educational Policy \& Accreditation Standards-EPAS). The Educational Policy and Accreditation Standards (EPAS) established by the Council on Social Work Education (CSWE) set requirements for competency-based accreditation on cultural diversity. Spiritual and religious competencies fall into this category.

\section{Worldview Diagnostic Tree (WDT) Instrument}

The Worldview Diagnostic Tree (WDT) instrument was developed with the purpose of identifying students' worldviews (Figure 1). The instrument is built on the principles of the well-known DSM Diagnostic Trees. The process of diagnosis follows the dialectic logic tree of positive and negative statements that eventually leads to a representative worldview. Similarly, as DSM - 5 diagnoses mental conditions on a continuum spectrum from health 
to pathology, so does the worldview model constructing life dispositions on religious/nonreligious, spiritual/nonspiritual, conservative/liberal continuum in identifying individuals' perspectives on theological, political, economic and social issues. Dissimilar to DSM - 5, though, the worldview model doesn't consider either extreme of the spectrum to be pathological. The ability to classify personal views on a broad scale is advantageous in capturing the cultural, political, and religious diversity in the mental health field. Its continuum structure is inclusive of diverse opinions, beliefs and practices from the professional social work field.

\section{WORLDVIEW DIAGNOSTIC TREE}

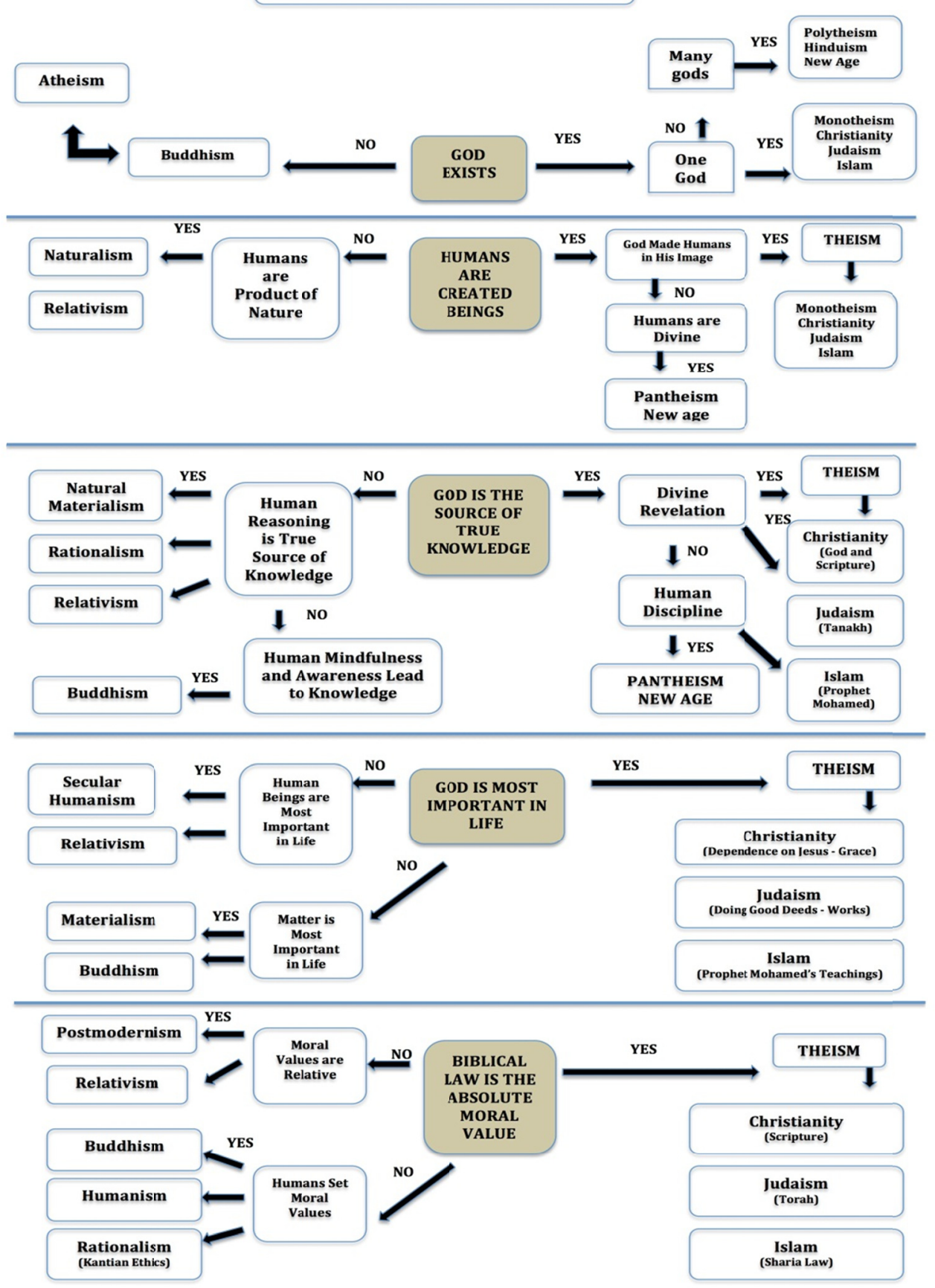

Figure 1. Worldview diagnostic tree instrument 
The philosophical framework of WDT is based on Sire's (2004) and Cobern (1991) definitions of worldview. Sire defines it as "... a commitment, a fundamental orientation of the heart, that can be expressed as a story or in a set of propositions (assumptions which may be true, partially true or entirely false) which we hold (consciously or subconsciously, consistently or inconsistently) about the basic constitution of reality, and that provides the foundation on which we live and move..." (Sire, p. 122). Similarly, a decade earlier Cobern (1991) defined worldview as "culturally-dependent, generally subconscious, fundamental organization of the mind that manifests itself as a set of presuppositions or assumptions, which predispose one to feel, think, and act in predictable patterns" (p. 3). Both definitions acknowledge the foundational role of intellectual structures in worldview formation but it further expands its meaning to account for human emotions, attitudes, and commitments. Both models are compatible with the values of the social work profession embedded in the service of empathy and compassion.

The structure of WDT is built on Poplin's (2014) classification of worldviews as Theistic, Polytheistic, Naturalistic and Secular Humanistic. The five-dimensional structure (Figure 2) that represents beliefs from theological, ontological, epistemological, axiological and deontological perspectives is a modified version of Martin's (2006) worldviews dimensional concept. On the chart, five statements take the central place epitomizing each of the five dimensions. These are modified constructs of Sire's (2004) basic questions of life on external reality, personhood, death, knowing and morality.

The first three dimensions - theological, ontological and epistemological - contain the philosophical structure of a worldview. The central questions inquire about beliefs in God as creator of human life and the source of true knowledge. The chart acknowledges the diversity of beliefs on broad spectrum from theistic (Judaism, Christianity and Islam), polytheistic (Hinduism, paganism, pantheism, Shinto, Wicca, New Age) and atheistic (Natural Materialism, Rationalism, Relativism, some forms of Buddhism, Secular Humanism, Postmodernism).

The Theological dimension is fundamental for the build-up of a worldview. The statement, "God Exists" delineates between acknowledgment and denial of a divine existence. It carries a foundational function that predisposes the worldview orientations in the remaining four dimensions. While the accuracy of these assumptions is stronger for the first three dimensions, the last two dimensions - axiological and deontological - deviate from this expectation because they form the ethical structure of a worldview. This function of the WDT accounts for individuals who may identify as theologically conservative but socially liberal. A large number of social workers' worldviews might naturally fall under this categorization due to the fact that many have made commitment to the profession as a personal response to a higher calling.

The biblical worldview in this study was defined with beliefs that the Bible is divinely inspired and accurate in all of the principles it teaches; Satan is a real being; biblical curses and blessings are in effect today; God is the all-knowing, all-powerful creator of the world who continuously oversees the yesterday, today, and tomorrow of the universe; absolute moral truth and values exist. 


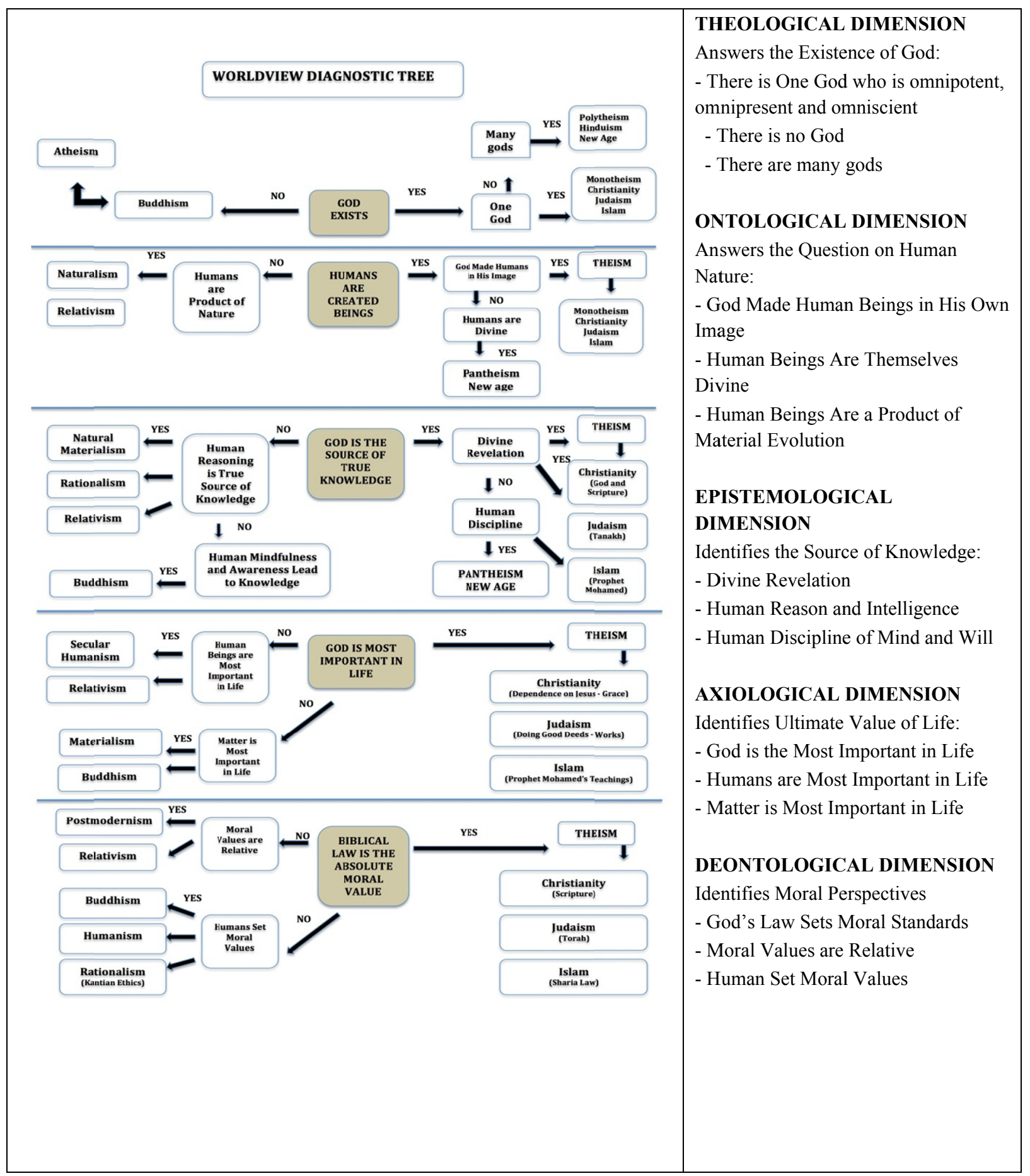

Figure 2. WDT structure - theological, ontological, epistemological, axiological and deontological dimensions

Positions on the ontological and epistemological questions are naturally influenced by the beliefs expressed at the theological level. The ontological question, "Humans are created beings," inquires about the essence of human nature. Beliefs that human beings are created in the image of God are congruent with the theistic understanding expressed by Judaism, Christianity and Islam. The practice of New Age and polytheism deviates from this belief, claiming the divine nature of human beings. On the other spectrum of the chart are positioned beliefs that human beings are product of natural causes and chance via evolutionary process. 


\section{Methodology}

The literature review for this study conducted searches of PsycINFO, SocINDEX, ERIC, MEDLINE, and CINAHL, Christian Periodical Index, and ALTA Religion Database, using keywords related to "worldviews", "spirituality", "religion", and social work education. Search parameters were defined linguistically to "English language" and academically to "peer reviewed".

The implementation of WDT instruments yielded five options for worldview identification along the five dimensions of its worldview structure, classifying them into: (1) Biblical Theism, (2) Moderate Christian, (3) Secular Humanism and (4) Material Naturalism.

This study also utilized the Worldview Diagnostic Scale (WDS) (Neshama-Bannister, 2016) as a complementary instrument for worldview identification and comparison (Table 1). WDS is a survey that positions participants' answers on a seven-level scale. For all items the following scoring scale was used: agree without reservations $=0$, agree with reservations $=1$, not completely agree $=2$, more agree than disagree $=3$, more disagree than agree $=4$, not completely disagree $=5$, disagree with some objections $=6$, completely disagree $=7$. Lower scores correspond to conservative worldviews and higher scores correspond to liberal worldviews. For the purpose of comparison between WDS and WDT scores, the former were equalized with an adjustment of its raw indexes: nominal values between 0 and 1 were categorized as 1 , representing the Biblical Worldview; values between 1 and 3 were categorized as 2, representing Moderate Christian worldview; values between 3 and 5 were categorized as 3, representing Secular Humanism; values between 5-7 were categorized as 4, representing Material Naturalism.

Table 1. Worldview diagnostic scale instrument

\begin{tabular}{|c|c|}
\hline & WORLDVIEW DIMENSIONS \\
\hline \multirow{4}{*}{ 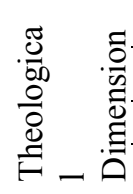 } & God is distant and not involved in human life and history \\
\hline & God created humans in His own image \\
\hline & Life begins at conception \\
\hline & Death is not the end of human existence \\
\hline \multirow{4}{*}{ 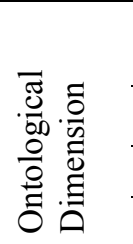 } & $\begin{array}{l}\text { Recognition of wrongdoing (repentance) is the first step towards mental, emotional and } \\
\text { physical healing }\end{array}$ \\
\hline & Existential fear of death is lack of peace (uncertainty in one's eternal destiny) \\
\hline & The human spirit, like the mind and the body, is prone to illness \\
\hline & Attaining God's holiness brings mental, physical, and spiritual healing \\
\hline \multirow{5}{*}{ 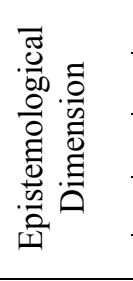 } & Seeking the guidance of the holy spirit is crucial for successful counseling/therapy \\
\hline & Prayer should be part of the therapeutic process for healing \\
\hline & Biblical curses and blessings are in effect today \\
\hline & Demonic possession should be considered in mental health diagnostic assessment \\
\hline & Gender roles are divinely assigned \\
\hline \multirow{8}{*}{ 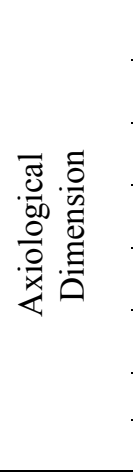 } & The biblical mandate to help the poor should be replaced by government welfare \\
\hline & The welfare state is the answer to poverty \\
\hline & Strong private property rights policy creates an unjust society \\
\hline & Governmental redistribution of wealth is a just practice \\
\hline & The global society can completely eradicate world poverty \\
\hline & The government is responsible for the general wellbeing of all citizens \\
\hline & World bank should unconditionally forgive the debts of poor nations \\
\hline & When one person becomes rich another person automatically becomes poor \\
\hline \multirow{3}{*}{ 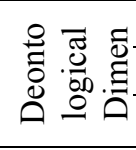 } & Moral values must change as society becomes more progressive \\
\hline & People can build a just society without Judeo-Christian values \\
\hline & The ten commandments are outdated norms of living \\
\hline
\end{tabular}


Previous studies have confirmed the WDS instrument's internal consistency and reliabilities (Neshama-Bannister, 2016). This methodology allows for an appraisal of the compatibility between both instruments with the expectation to derive similar data from identical variables.

The pretest and posttest research methodology was designed with the expectation that our pedagogical interventions for integration of spirituality and religion in social work curricula will have significant effect on the research outcome. A significant difference in scores between the means of the pretest and posttest were expected to provide evidence that learning took place as a direct result of the designed intervention. The desired pedagogical methodology constituted a well-structured course material spread across fifteen (15) sessions as part of the SOCW 513: Micro-Theory and Human Development course taught in the MSW Department at Azusa Pacific University in the 2014-2015 fall semester. Ten of the sessions were designed for intentional integration of spirituality and religion via worldview instructions (Table 2). Main instructional material was Poplin's (2014) Is reality secular? Testing the assumptions of four global worldviews book. For this 3-unit course students were expected to: 1) attend approximately three hours per week of classroom or direct faculty instruction and 2) engage in out-of-class work of approximately nine hours each week.

Table 2. Integration of spirituality and religion in SOCW 513: Micro-theory and human development course curriculum

\begin{tabular}{cll}
\hline $\begin{array}{c}\text { Week } \\
\text { Session }\end{array}$ & \multicolumn{1}{c}{ Topic } & \multicolumn{1}{c}{ Assigned Required Reading } \\
\hline 1 & Worldview as operating system & Introductory Lecture \\
\hline 2 & History of worldview formation & Is Reality Secular? Ch. 1-4 \\
\hline 3 & Material naturalism - worldview & Is Reality Secular? Ch. 5, 6, 7 \\
\hline 4 & Ethical dilemmas raised by different worldviews & Is Reality Secular? Ch. 8, 9, 10 \\
\hline 5 & Secular Humanism - worldview & Is Reality Secular? Ch. 11, 12, 13 \\
\hline 6 & Principles of secular and Christian psychology & Is Reality Secular? Ch. 14, 15, 16, 17 \\
\hline 7 & Pantheism - worldview & Is Reality Secular? Ch. 18, 19, 20 \\
\hline 8 & Spirituality in counselling and therapy & Is Reality Secular? Ch. 21, 22, 23 \\
\hline 9 & Judeo-Christian worldview & Is Reality Secular? Ch. 24, 25, 26, 27 \\
\hline 10 & Compare \& contrast worldviews & Concluding Lecture \\
\hline
\end{tabular}

The academic curriculum was built on the task of methodically introducing predominant global worldview traditions and integrating them in students' course requirement for assessment and intervention strategies (Competencies 7 and 8 of the CSWE 2015 Educational Policy \& Accreditation Standards-EPAS).

The data was collected in the beginning and at the end of the SOCW 513: Micro-Theory and Human Development course through 1) in-class administration of a pen-and-paper version of the Worldview Diagnostic Tree instrument and 2) an online Worldview Diagnostic Scale survey disseminated via Google Forms in September 2015 to 32 foundational year MSW students from Azusa Pacific University. The obtained responses formed a single data set utilized to examine whether students' self-professed worldviews differ from the worldviews identified through the use of WDT instrument.

Two class assignments were geared for practice and outcome evaluation of students' ability to integrate spirituality and religion in their field practice: 1) in-class field case presentations and 2) integrative research papers. Both assignments required that students: 1) present bio-psychosocial and spiritual assessment on actual field placement cases and 2) apply major worldview frameworks to their cases and discuss how their personal worldview influences the choice of treatment plan.

Statistical analysis was conducted using IBM SPSS Statistics for Macintosh, Version 22.0. Exploratory factor analysis with maximum likelihood extraction method, using a VARIMAX rotation with Kaiser normalization was applied for the study of the instrument's factor model. Cronbach's alpha was calculated to determine whether the WDS instrument produces reliable data in terms of internal consistency. An exploratory factor analysis aimed to identify the dimensionality of the instrument and the computation of Cronbach's Alpha showed its internal reliability. The value of 
Cronbach's Alpha was judged according to the scale of George \& Mallery (2003): $\geq .9$ - Excellent, $\geq .8-$ Good, $\geq .7-$ Acceptable, $\geq .6$ - Questionable, $\geq .5$ - Poor, and $\leq .5$ - Unacceptable (p. 231).

Differences between group variables were determined with the application of the $t$ - test for paired variables. MANOVA analysis was employed for the study of the relationship between multiple variables representing the five-dimensional worldview derived from the WDS instrument and the scores from the WDT instrument.

\section{Results and Analysis}

The sample was subjected to examination of the psychometric properties of the WDS instrument. The data yielded satisfactory levels of Cronbach's Alpha of .813, indicating that the instrument produces reliable data in terms of internal consistency. The Cronbach's Alpha results from WDS were compatible to earlier findings (Neshama-Bannister, 2016).

Our approach of investigation begins with an analysis of the compound data from the instruments' scores (pretest and posttest). It methodically progresses on a more detailed level with an analysis of the instruments' five-dimensional structure as yielded by WDT's pretest and posttest scores. This research methodology allows the investigation to trace the significant effect between multiple variables on different levels of relationships.

Paired $t$-test was applied to examine whether students' religious self-identification differ from their scores as derived from the WDS and WDT instruments (Table 3). The scores were derived from compounding each instrument's five-dimensional pretest and posttest subscores. The results show a significant difference in the scores for WDT $(\mathrm{M}=2.22 ; \mathrm{SD}=1.02)$ and self-identified religious affiliation $(\mathrm{M}=1.16 ; \mathrm{SD}=.628) ; t(31)=3.85, p<.0001$. Similarly, significant difference also was found in the scores for WDS $(\mathrm{M}=2.31 ; \mathrm{SD}=1.01)$ and self-identified religious affiliation $(\mathrm{M}=1.16 ; \mathrm{SD}=.628), t(31)=-5.75, p<.0001$. The results display the existence of discrepancies between students' self-identified religious affiliation and the religious identification as measured separately by both worldview instruments.

Table 3. Differences between students' self-identified religious affiliation and the religious identification as measured by WDS and WDT instruments

\begin{tabular}{cccccc}
\hline Worldviews & Mean & SD & $\boldsymbol{t}$ & df & $\begin{array}{c}\boldsymbol{p} \\
\text { (2-tailed) }\end{array}$ \\
\hline Religious ID & 1.16 & .628 & -5.75 & 31 & $<.0001$ \\
\cline { 1 - 3 } WDT & 2.22 & 1.01 & & & \\
\hline WDS & 2.31 & .692 & -8.53 & 31 & $<.0001$ \\
\hline
\end{tabular}

Paired $t$-test was also applied to the independent compound scores of the WDS and WDT instruments to determine their compatibility (Table 4). There was no significant difference in the scores for WDT $(\mathrm{M}=2.21 ; \mathrm{SD}=1.01)$ and WDS $(\mathrm{M}=2.31 ; \mathrm{SD}=.692) ; t(31)=.770, p=.447$. The results indicated that both instruments yielded similar information.

Table 4. Compatibility between WDS and WDT instruments

\begin{tabular}{|c|c|c|c|c|c|}
\hline Worldviews & Mean & SD & $\mathbf{t}$ & df & $\begin{array}{c}p \\
\text { (2-tailed) }\end{array}$ \\
\hline WDS & 2.31 & .692 & .770 & 31 & .447 \\
\hline WDT & 2.21 & 1.01 & & & \\
\hline
\end{tabular}

\section{Relationship between Pre and Post WDT Five-Dimensional Scores and MSW Students' Self-Identified Religious Affiliation}

To test the assumption that variances are equal across the groups, we employed Levene's test of equality of error variances. Results confirmed the further applicability of MANOVA and ANOVA, satisfying the test's assumptions: Theological Dimension $F(30,11)=.007, p<.933$, Ontological $\mathrm{F}(30,9.1)=.001, p<.901$, Epistemological $\mathrm{F}(30$, $9.99)=1.45, p<.236$; Axiological $\mathrm{F}(30,10.27)=.007, p<.993$; Deontological $\mathrm{F}(30,14.47)=.793, p<.38$. 
A detailed analysis called for further examination of WDT pretest and posttest data. One-way MANOVA was employed to determine if participants' self-identified religious affiliation differed from the scores derived from pretest and posttest WDT scores. Wilks' Lambda test of variances didn't yield significant levels for pretest values, [Wilks' $\left.\Lambda=.756, F(5,26)=1.67, p<.176, \eta^{2}=.24\right]$. Posttest data of students' self-identified religious affiliation, however, was found to differ statistically significantly for post WDT scores, [Wilks' $\Lambda=.518, F(5,26)=4.83, p$ $\left.<.003, \eta^{2}=.48\right]$ with 48 percent of multivariate variances being associated with the group factor.

The test of the between-subject factor identified that in the WDT posttest only the Deontological Dimension differed significantly from students' self-identified religious identification, $\mathrm{F}(1,30)=5.38, p<.027$ (Table 5). This dimension is strongly related to deeply expressed biblical values. The pretest and posttest data suggest that the group as a whole moved way from homogeneity. While in the results from pretest only 24 percent accounted for differences between subjects, the posttest differences rose to 48 percent. Further investigation explored the direction of these changes as expressed through self-identified religious affiliation (Table 6).

Table 5. Relationship between self-identified religious affiliation (RID) and five-dimensional WDT components

\begin{tabular}{|c|c|c|c|c|c|}
\hline \multirow[t]{2}{*}{ Worldviews } & \multicolumn{2}{|c|}{ RID } & \multirow{2}{*}{$\begin{array}{c}\text { Mean } \\
\text { Square }\end{array}$} & \multirow[t]{2}{*}{$\mathbf{F}$} & \multirow[t]{2}{*}{$p$} \\
\hline & Mean & SD & & & \\
\hline \multicolumn{6}{|c|}{ WDT Pretest } \\
\hline Theological & 1.23 & .678 & 1.01 & 1.27 & .269 \\
\hline Ontological & 1.43 & .759 & .408 & .571 & .456 \\
\hline Epistemological & 1.53 & .915 & .408 & .522 & .476 \\
\hline Axiological & 1.82 & 1.12 & .000 & .000 & 1.00 \\
\hline Deontological & 1.87 & 1.18 & .352 & .372 & .546 \\
\hline \multicolumn{6}{|c|}{ WDT Posttest } \\
\hline Theological & 1.09 & .530 & .019 & .65 & .801 \\
\hline Ontological & 1.18 & .644 & 1.41 & 3.68 & .064 \\
\hline Epistemological & 1.34 & .787 & .919 & 1.506 & .229 \\
\hline Axiological & 1.34 & .787 & .052 & .082 & .777 \\
\hline Deontological & 1.72 & 1.19 & 6.77 & 5.38 & $.027 *$ \\
\hline
\end{tabular}

Note: $* \mathrm{p}<.05$

Paired $t$-test was employed to examine the differences of WDT pretest and posttest scores (Table 6). The results showed statistically significant differences for pretest and posttest scores for the Ontological Dimension $t(131)=2.78$, $p<.009$ and pretest and posttest scores for the Axiological Dimension $t(31)=3.02, p=.005$. As judged by the mean values, the group's posttest scores for the Ontological Dimension moved towards the more conservative end of the scale from $\mathrm{M}=1.43 \pm .75$ to $\mathrm{M}=1.18 \pm .64$. Similarly, the group scores for the Axiological Dimension follow a similar dynamic, moving towards the conservative end of the scale from $\mathrm{M}=1.81 \pm 1.12$ to $\mathrm{M}=1.34 \pm .78$.

Table 6. Paired t-test for mean differences of WDT pretest and posttest scores

\begin{tabular}{|c|c|c|c|c|c|}
\hline & Mean & SD & $t$ & df & $\begin{array}{c}p \\
\text { (2-tailed) }\end{array}$ \\
\hline Theological pretest & 1.22 & .659 & 1.68 & 31 & .103 \\
\hline Theological posttest & 1.09 & .530 & & & \\
\hline Ontological pretest & 1.43 & .759 & 2.78 & 31 & $.009 * *$ \\
\hline Ontological posttest & 1.18 & .644 & & & \\
\hline Epistemological pretest & 1.53 & .915 & 1.64 & 31 & .110 \\
\hline Epistemological posttest & 1.34 & .787 & & & \\
\hline Axiological pretest & 1.81 & 1.12 & 3.02 & 31 & $.005 * *$ \\
\hline Axiological posttest & 1.34 & .787 & & & \\
\hline Deontological pretest & 1.87 & 1.18 & .961 & 31 & .344 \\
\hline Deontological posttest & 1.72 & 1.19 & & & \\
\hline
\end{tabular}

Note: $* p<.05 ; * * p<.001$ 
Posttest scores from the WDT instrument indicate a significant shift of participants' worldview towards the more conservative end of the scale. These changes are consistent in all five dimensions of the WDT instrument (Table 7). At the beginning of the course the scores of 87 percent of participants fell within the Biblical Theism worldview. At the end of semester this number rose to 97 percent. Similar increase was observed across the remaining four dimensions. The Ontological Dimension increased at the end of semester from 69 percent to 91 percent, the Epistemological Dimension from 69 percent to 81 percent, the Axiological Dimension from 62 percent to 78 percent and the Deontological Dimension from 62 percent to 72 percent.

The increase of percentage points for the Biblical Theism worldview comes predominantly from the Moderate Christian worldview. For the Ontological Dimension the number of participants identifying with the Moderate Christian worldview dropped from 22 percent to 3 percent at the end of the class. These participants, 19 percent, whose scores initially affiliated with the Moderate Christian worldview affiliated with the Biblical Theism worldview at the end of semester. Similarly, the pretest and posttest scores for the Epistemological Dimension dropped from 16 percent to 6 percent, respectively. The increased percentage points of the Axiological Dimension, however, appear to have been gained from the Secular Humanism part of the scale: 25 percent in the beginning of the semester changed to 0 percent at the end of semester.

Table 7. Comparative distributions among the five dimensions of the WDT instrument

\begin{tabular}{ccccccccccc}
\hline Worldviews & \multicolumn{2}{c}{ Theological } & \multicolumn{2}{c}{ Ontological } & \multicolumn{2}{c}{ Epistemological } & \multicolumn{2}{c}{ Axiological } & \multicolumn{2}{c}{ Deontological } \\
\cline { 2 - 10 } & Pre & Post & Pre & Post & Pre & Post & Pre & Post & Pre & Post \\
\hline $\begin{array}{c}\text { Biblical } \\
\text { Theism }\end{array}$ & $87.5 \%$ & $96.9 \%$ & $68.8 \%$ & $90.6 \%$ & $68.8 \%$ & $81.3 \%$ & $62.5 \%$ & $78.1 \%$ & $62.5 \%$ & $71.9 \%$ \\
\hline $\begin{array}{c}\text { Moderate } \\
\text { Christian }\end{array}$ & $6.3 \%$ & ---- & $21.9 \%$ & $3.1 \%$ & $15.6 \%$ & $6.3 \%$ & $3.1 \%$ & $15.6 \%$ & $25 \%$ & $15.6 \%$ \\
\hline $\begin{array}{c}\text { Secular } \\
\text { Humanism }\end{array}$ & $3.1 \%$ & ---- & $6.3 \%$ & $3.1 \%$ & $9.4 \%$ & $9.4 \%$ & $25 \%$ & ---- & $12.5 \%$ & $12.5 \%$ \\
\hline $\begin{array}{c}\text { Material } \\
\text { Naturalism }\end{array}$ & $3.1 \%$ & 3.1 & $3.1 \%$ & $3.1 \%$ & $6.3 \%$ & $3.1 \%$ & $9.4 \%$ & $6.3 \%$ & ---- & ---- \\
\hline
\end{tabular}

Repeated measure ANOVA was also applied to investigate how WDS and pretest and posttest WDT scores compare across MSW students' clinical and community concentrations (Table 8). The results showed no significant differences between concentration and WDS and pretest and posttest WDT scores [Wilks' $\Lambda=.892, F(5,26)=.627, p$ $\left.<.681, \eta^{2}=.02\right]$.

Table 8. WDT pretest and posttest scores according to concentration specialization

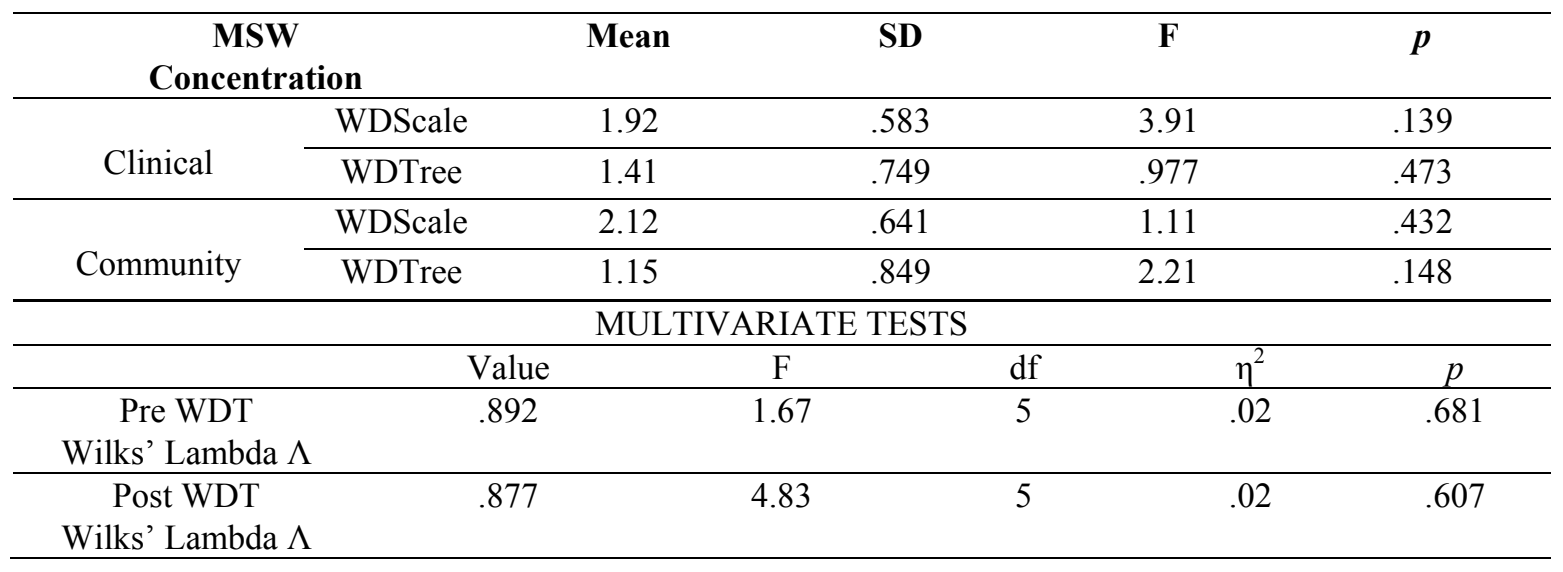

ANCOVA analysis was applied to compare the effect of MSW concentration specialization on the WDT pretest and posttest scores, measuring the five dimensions of participants' worldviews. The study did not find significant effect of the concentration factor (clinical or community) on pretest/posttest scores for Theological Dimension $[\mathrm{F}(1,30)=1.18$, 
$\mathrm{p}=0.572]$, Ontological Dimension $[\mathrm{F}(1,30)=1.85, \mathrm{p}=0.350]$, Epistemological Dimension $[\mathrm{F}(1,30)=2.18, \mathrm{p}=$ $0.704]$, Axiological Dimension $[\mathrm{F}(1,30)=2.85, \mathrm{p}=0.383]$, and Deontological Dimension $[\mathrm{F}(1,30)=3.18, \mathrm{p}=0.357]$ (Table 9).

Table 9. WDT pretest and posttest for clinical and community concentration cohorts

\begin{tabular}{|c|c|c|c|c|c|c|c|c|}
\hline \multirow{2}{*}{\multicolumn{2}{|c|}{$\begin{array}{l}\text { MSW Concentration/ } \\
\text { Worldview Dimensions }\end{array}$}} & \multicolumn{2}{|c|}{ Mean } & \multicolumn{2}{|c|}{ SD } & \multirow{3}{*}{$\begin{array}{c}\mathbf{F} \\
1.18\end{array}$} & \multirow{3}{*}{$\begin{array}{c}\mathbf{d f} \\
1,30\end{array}$} & \multirow{3}{*}{$\begin{array}{c}\boldsymbol{p} \\
.572\end{array}$} \\
\hline & & \multirow{2}{*}{$\begin{array}{l}\text { pre } \\
1.29\end{array}$} & \multirow{2}{*}{$\frac{\text { post }}{1.12}$} & \multirow{2}{*}{$\begin{array}{l}\text { pre } \\
.750\end{array}$} & \multirow{2}{*}{$\frac{\text { post }}{.612}$} & & & \\
\hline Clinical & Theological & & & & & & & \\
\hline Community & & 1.00 & 1.00 & .000 & .000 & & & \\
\hline Clinical & \multirow[t]{2}{*}{ Ontological } & 1.54 & 1.25 & .832 & .737 & 1.85 & 1,30 & .350 \\
\hline Community & & 1.12 & 1.00 & .353 & .000 & & & \\
\hline Clinical & \multirow[t]{2}{*}{ Epistemological } & 1.66 & 1.37 & 1.01 & .168 & 2.18 & 1,30 & .704 \\
\hline Community & & 1.12 & 1.25 & .353 & .250 & & & \\
\hline Clinical & \multirow[t]{2}{*}{ Axiological } & 1.41 & 1.41 & .881 & .881 & 2.85 & 1,30 & .373 \\
\hline Community & & 1.12 & 1.12 & .353 & .707 & & & \\
\hline Clinical & \multirow[t]{2}{*}{ Deontological } & 1.83 & 1.23 & 1.23 & .253 & 3.18 & 1,30 & .357 \\
\hline Community & & 1.37 & 1.06 & 1.06 & .375 & & & \\
\hline
\end{tabular}

Note: $* \mathrm{p}<.05 ; * * \mathrm{p}<.001$

\section{Discussion}

The results of this investigation rejected the null hypothesis, confirming the alternative $\mathrm{H} 0: \mu=0-\mathrm{H} 1: \mu \neq 0$ hypothesis. The study found that participants' self-identified religious affiliation differed statistically significantly from their scores as measured by WDS and WDT instruments. Both instruments were subjected to an extended analysis to ensure their compatibility. The results showed no statistically significant differences between the raw scores of each instrument. The results confirmed the expectations for compatibility of both instruments.

Means comparison between WDT $(\mathrm{M}=2.22)$ and self-identified religious affiliation $(\mathrm{M}=1.16)$ indicates that at the end of the study participants self-identified more conservatively compared to the pretest WDT scores, which placed them towards the liberal scores on the scale. At the beginning of the study, a majority of the participants, almost $94 \%$ percent, self-identified as Christians (Table 10). Measured through the WDS instrument this number dropped to 84 percent (Biblical Theism and Moderate Christian combined). The percentage of participants aligned with Christian beliefs (Biblical Theism and Moderate Christian combined) dropped even further to 75 percent as measured through the WDT. Consequently, at the end of semester, the WDT posttest scores measured significantly higher, at 88 percent, exceeding the prettest levels of WDS and WDT scores.

Table 10. Comparative distributions among religious self-identification, WDS and WDT instruments

\begin{tabular}{ccccc}
\hline Worldviews & Religious Self-ID & WDT pretest & WDT posttest & WDS \\
\hline Biblical Theism & $93.8 \%$ & $62.5 \%$ & $72 \%$ & $18.8 \%$ \\
\hline Moderate Christian & ----- & $12.5 \%$ & $15.6 \%$ & $65.6 \%$ \\
\hline Secular Humanism & $6.2 \%$ & $18.8 \%$ & $9.3 \%$ & $15.6 \%$ \\
\hline Material Naturalism & $0 \%$ & $6.2 \%$ & $3.1 \%$ & $0 \%$ \\
\hline
\end{tabular}

The observed dynamics show that as the SOCW 513: Micro-Theory and Human Development course progressed, the differences in the students' scores narrowed between their initially self-identified religious affiliation and their religious identification as measured through WDT, $F(5,26)=4.83, p<.003$. Earlier studies have found that college/university level students' worldviews are stably established structures (Mayhew, Bowman \& Rockenbach, 2014; Neshama-Bannister, 2016). The findings from our study then, suggest that the statistically significant changes between pretest and posttest results, as measured through WDT instrument (Table 5), were due to the effect of course material as outlined in the course syllabus (Table 2). We can confidently say that the course materials have contributed to students' more accurate religious self-identification. 
Identified discrepancy between self-identified religious affiliation and the WDT scores $\mathrm{F}(1,30)=5.38, p<.027$ (Table 5 ), appears to be strongly related to deontological ethics that identifies participants' moral perspectives. This is the moral value area of one's worldview that seeks unwavering loyalty to the biblical law as criteria for social justice. It counter-positions three possible perspectives. The first position affirms that God's law sets societal moral standards and this view aligns with the Christian worldview. The second view holds that moral standards and values are relative and aligns with postmodernism and relativism as a life perspective. The third position gives credit to human beings for creating their own set of moral values and is congruent with Buddhism and Kantian ethics as expressed in humanism and relativism. The pretest $(\mathrm{M}=1.87, \mathrm{SD}=1.18)$ and posttest $(\mathrm{M}=1.72, \mathrm{SD}=1.19)$ results for the Deontological Dimension, between self-identified religious affiliation and the religious identification as measured through WDT instrument, suggest that as the semester progressed participants moved towards the more conservative end of the scale (Table 5).

The search for deeper understanding of the above-discussed dynamics directed the research towards identifying which of the WDT dimensions of participants' worldviews have changed along one semester and statistically differed at the end of the class. Data analysis pointed to two of the dimensions where substantial changes have occurred. WDT scores for the Ontological and Axiological dimensions showed statistically significant differences (Table 6). The direction towards which all worldview dimensions changed showed more conservative scores but only the scores of the Ontological and Axiological dimensions were found to significantly differ from pretest and posttest scores.

The Ontological Dimension addresses questions related to the understanding of human nature. WDT offers three options. Option one represents the Biblical Theism worldview, asserting the divine design in the creation of the human beings as made in the image of God. The second option, representing the polytheistic worldview, holds the belief that human beings are themselves divine. The third option proceeds from an atheistic perspective, holding the view that human beings are a product of material evolution.

The content of SOCW 513: Micro-Theory and Human Development course examined these three positions through comparative analysis of different theoretical frameworks guiding the understanding of human nature as applied to different therapeutic approaches. While the Freudian view on human nature looked at the genetic factors (sexual and aggressive drives) as primary, Sartre's existential view on human nature placed the entire responsibility within the human will as freedom of choice. While Freud viewed religious beliefs and practices as expression of existential fear of death, Kierkegaard saw this as lack of peace with God due to uncertainty in one's eternal destiny. It appears that participants' understanding of human nature shifted away from Freud to align more with Kierkegaard's view.

The statistically significant differences found for Axiological Dimension are related to the task of identifying the ultimate value of life. Under WDT's structure, associated with the biblical theistic view, is the understanding that God is most important in life. By the end of semester, participants appear to have significantly agreed with this view, moving away from the humanistic (humans are most important in life) and atheistic (matter is most important in life) views.

The research team acknowledges the fact that the study was conducted with participants at an accredited MSW program placed within a religious institution, Azusa Pacific University, and that the results may have been impacted by students' personal commitments to the Christian faith. Earlier studies, however, didn't show statistically significant differences in worldview change within a one semester course (Neshama-Bannister, 2016). This gives us confidence to attribute the changes found in this particular study to the specially designed worldview curriculum content (Table 2).

Further, the study didn't find differences between the WDT and WDS scores of community and clinical concentration cohorts $F(5,26)=.627, p<.681$ (Table 8). Similarly, the results from pretest and posttest for all five worldview dimensions of the WDT instrument display no statistically significant differences (Table 9). The homogeneity of the clinical and community cohorts showed consistency even with the captured changes within the semester. The changes in worldview scores affected the entire sample and were not due to concentration specialization.

\section{Conclusion}

Results from WDT pretest suggest that while the boundaries of conservative and liberal worldviews are distinctive and clear, there is observed compromise among participants with moderate Christian worldviews. The compromise extends even to more conservative participants with Biblical Theism worldviews when the area being compromised is directly related to the social work field. The results from the WDS instrument at the beginning of class suggest that the worldviews of participants who identify as having Biblical Theism worldviews enmesh with Material 
Naturalistic worldviews on the issue of human nature as stated in Theological, Ontological and Epistemological Dimensions and on the issues of social justice as stated in Axiological and Deontological Dimensions. On issues of recognizing the guidance of the Holy Spirit, the power of prayer and the existence of demonic possession, even the most conservative participants chose to align with the atheistic worldview as measured by the WDS instrument at the beginning of the class. The WDS scores, however, shiftet at the end of the semester towards the conservative end of the scale, indicating realignment more consistent with Biblical Theism worldview.

In conclusion we state that these dramatic changes in participants' worldviews are not indicative of a transformational experience during SOCW 513: Micro-Theory and Human Development course (Vokey, 2012). This is a foundational graduate social work course that has no religious objectives but for the academic integration of spirituality and religion into the course syllabus (Table 2). We attribute the observed changes to participants' increased ability to self-identify their religious affiliation. The pedagogy of the worldview section of the course was not geared towards an experiential development of participants' worldviews but towards expansion of their cognitive capacity to self-identify with their professed religion or spiritual practice. This is an enhanced pedagogical approach disseminating information of the tenets of major spiritual and religious practices around the globe via face-to-face, classroom instructions.

\section{References}

Adams, C. M., Puig, A., Baggs, A., \& Wolf, C. P. (2015). Integrating Religion and Spirituality into Counselor Education: Barriers and Strategies. Counselor Education \& Supervision, 54(1), 44-56. doi:10.1002/j.1556-6978.2015.00069.x

Barker, S. L. (2007). The Integration of Spirituality and Religion Content in Social Work Education: Where We've Been, Where We're Going. Social Work \& Christianity, 34(2), 146-166.

Barna, G. (2009). The seven faith tribes: who they are, what they believe, and why they matter. Tyndale House Publishers, Inc. Brentwood, TN.

Bender, C. (2010). The New Metaphysicals: Spirituality and the American Religious Imagination. University of Chicago Press. Chicago, IL.

Bishop, G. (1999). What Americans really believe and why faith isn't as universal as they think. Free Inquiry, 38.

Bowman, N. A., Rockenbach, A. N., \& Mayhew, M. J. (2015). Campus Religious/Worldview Climate, Institutional Religious Affiliation, and Student Engagement. Journal of Student Affairs Research \& Practice, 52(1), 24. http://dx.doi.org/10.1080/19496591.2015.996045

Buckey, J. W. (2012). Empirically Based Spirituality Education: Implications for Social Work Research and Practice. Journal of Social Service Research, 38(2), 260-271. http://dx.doi.org/10.1080/01488376.2011.647979

Canda, E., \& Furman, L. (2010). Spiritual diversity in social work practice: The Heart of Helping (2nd ed.). New York: Oxford University Press.

Chaves, M. (2011). American Religion: Contemporary Trends. Princeton University Press, Princeton, NJ.

Danto, E. A. (2008). Same Words, Different Meanings: Notes Toward a Typology of Postmodern Social Work Education. Social Work Education, 27(7), 710-722. http://dx.doi.org/10.1080/02615470701607531

Gallup Historic Trends. (2015). Retrieved from http://www.gallup.com/poll/1690/Religion.aspx?version=print

Gallup, G. Jr. (1995). Religion in America: Will the Vitality of Churches Be the Surprise of the Next Century? The Public Perspective, 6(1), 1-8.

Gallup, G. Jr. (1997). Weekly Church Attendance Dips to Lowest Level in Six Decades. Emerging Trends, 19(3). Princeton Religious Research Center.

George, D., \& Mallery, P. (2003). SPSS for Windows step by step: A simple guide and reference. 11.0 update (4th ed.). Boston: Allyn \& Bacon.

Gerson, J., Allen, R., Gold, J., \& Kose, G. (2000). Multiple Belief Systems in Psychotherapy: The Effects on Religion and Professional Beliefs on Clinical Judgment. Journa of Contemporary Psychotherapy, 30(1), 27-32.

Hunt, J. (2014). Bio-Psycho-Social-Spiritual Assessment? Teaching the Skill of Spiritual Assessment. Social Work \& Christianity, 41(4), 373-384.

IBM Corp. (2013). IBM SPSS Statistics for Windows, Version 22.0. Armonk, NY: IBM Corp. 
King, J., \& Trimble, J. E. (2013). The spiritual and sacred among North American Indians and Alaska Natives: Mystery, wholeness, and connectedness in a relational world. In K. I. Pargament, J. J. Exline, J. W. Jones, K. I. Pargament, J. J. Exline, \& J. W. Jones (Eds.), APA handbook of psychology, religion, and spirituality (Vol 1): Context, theory, and research (pp. 565-580). Washington, DC, US: American Psychological Association. http://dx.doi.org/10.1037/14045-031

Lugo, L., Stencel, S., Green, J., Smith, G., Cox, D., Pond, A., \& Ralston, M. (2008). U.S. Religious Landscape Survey: Religious Affiliation: Diverse and Dynamic. Washington DC: Pew Forum on Religion \& Public Life.

Mayhew, M., \& Bryant, A. (2013). Achievement or Arrest? The Influence of the Collegiate Religious and Spiritual Climate on Students' Worldview Commitment. Research in Higher Education, 54(1), 63-84. http://dx.doi.org/10.1007/s11162-012-9262-7

Moss, B. (2005). Thinking outside the box: religion and spirituality in social work education and practice. Implicit Religion, 8(1), 40-52.

Mulder, C. (2014). Unraveling Students' Experiences with Religion and Spirituality in the Classroom Using a Photovoice Method: Implications for MSW Programs. Social Work \& Christianity, 41(1), 16-44.

NASW. (1998). 100 Years of Professional Social Work: Centennial celebration. Retrieved from http://socialworkers.org/profession/centennial/default.htm

Neshama-Bannister, S. (2016). Worldview Pedagogy for Integration of Religion and Spirituality in Social Work Education. International Research in Higher Education, 1(1), 45-59.

Richards, P. S., \& Bergin, A. E. (1997). Western and Eastern spiritual worldviews. In A spiritual strategy for counselling and psychotherapy (pp. 49-74). Washington, DC, US: American Psychological Association. http://dx.doi.org/10.1037/10241-004

Rose, E. M., Westfeld, J. S., \& Ansley, T. N. (2001). Spiritual issues in counseling: Clients' beliefs and preferences. Journal of Counseling and Psychology, 48, 61-71.

Sire, J. (2004). Naming the Elephant: Worldview as a Concept. Downers Grove, IL: Inter Varsity Press Academic.

Stirling, B., Furman, L. D., Benson, P. W., Canda, E. R., \& Grimwood, C. (2010). A Comparative Survey of Aotearoa New Zealand and UK Social Workers on the Role of Religion and Spirituality in Practice. British Journal of Social Work, 40(2), 602-621. http://dx.doi.org/10.1093/bjsw/bcp008

Vokey, D. (2012). Spirituality and Professional Education: Contributions toward a Shared Curriculum Framework. In Sprituality and Social Work and Education: Theory, Practices, and Pedagogies. Wilfrid Laurier University Press, Ontario, Canada.

Wolf, S. M. (2011). The Shaping of a Professional Worldview in the Classroom: A Christian Psychology Project. Journal of Psychology \& Christianity, 30(4), 329-338.

Zucker, J. (2014). World Views: Creating Significance of Learning in the Classroom. Councilor: A Journal of the Social Studies, 75(1), 55-64. 